\title{
Social Time, Bodies and the "Logic of Waiting" in the Configuration of Urban Sensibilities
}

\author{
Ana Lucía Cervio ${ }^{1,2,3}$, Victoria D’hers ${ }^{1,2,3}$ \\ ${ }^{1}$ Centro de Investigaciones y Estudios Sociológicos (CIES), Buenos Aires, Argentina \\ ${ }^{2}$ Consejo Nacional de Investigaciones Científicas y Técnicas (CONICET), Buenos Aires, Argentina \\ ${ }^{3}$ Grupo de Estudio sobre Sociología de las Emociones y los Cuerpos, Instituto de Investigaciones Gino \\ Germani, Universidad de Buenos Aires, Buenos Aires, Argentina \\ Email: anacervio@hotmail.com, victoriadhers@gmail.com
}

Received 2 February 2014; revised 23 February 2014; accepted 7 March 2014

Copyright (C) 2014 by authors and Scientific Research Publishing Inc.

This work is licensed under the Creative Commons Attribution International License (CC BY). http://creativecommons.org/licenses/by/4.0/

(c) (i) Open Access

\begin{abstract}
Considering the acceleration of social time encouraged by the ever increasing speed in the circulation of goods and products in the current phase of capitalist development, it becomes essential to reflect on the configuration of social sensibilities. Particularly, the logic is embodied in the way city dwellers are, in their feelings and in their modes of possessing (physical things/property). Based on observations from Argentine life that illustrate the unequal access to basic urban services and goods, this article assesses the concept of "waiting mechanism" and its articulation with social sensibilities in peripheral urban contexts. The main assumptions of this analysis are that "waiting" affects bodies and that the experience of the city results from the class inter-play of social and bodily distance and proximity, which opens certain paths and closes others. From this standpoint, it is demonstrated that this "logic of waiting" yields feelings of helplessness socially reproduced through the assertion that "things will always be this way" and structured from the repetition of the experience of lacking (lack of access to basic sanitation, lack of possibilities of transportation, and so on). Thus, the emergence of "waiting" as an ability becomes problematic since it is one of the mechanisms manifesting the living conditions of people (and their historically constructed sensibilities) from the outskirts of cities in the twenty-first century.
\end{abstract}

\section{Keywords}

Social Time; Logic of Waiting; Social Sensibilities 


\section{Introduction}

“Better times will eventually come..."

Considering the current proliferation of objects and technologies associated with immediate delight, shortened distances, limitless communication and boundless interactions, the city appears to the observer as a privileged setting for the development and consumption of cultural and technological innovation, being both triumphs of the "information era". In this context, there are some widespread assumptions on how social relations are produced in the twenty-first century cities. It is common to hear that access to the Internet, mobile phones, GPS devices, webcams and digital photo cameras are instruments that stimulate flows and organize the time-space dimension. They multiply the ability to transmit and receive information, and influence the modes in which people conduct personal relationships, do business, do shopping, or learn (e.g. from the comfort of the office, a coffee-shop, or a park at any time). Nevertheless, these statements can be assessed critically from a socio-spatial interpretation anchored in the corporeal dimension of social relations. From this viewpoint, the impacts of ICTs on the development of urban life and the fantasy of immediacy resulting from it are limited (materially "slashed”) by subaltern spaces and circuits. Thus, the image of a segmented city emerges, one characterized by unequal access to material goods and differential sociabilities, emotions and rights.

Given this critical assessment of nowadays urban life, the experience of social time emerges as a key element to understand how city dwellers' sensibilities are structured, particularly those of the citizens inhabiting the urban periphery. As an expressive metaphor of the socio-vital sequence that permeates — while also constitutingthe interactions between subjects, social time can be understood as a dialectic relationship between Kronos and Kairos, i.e. as repetition and sudden manifestation, as the socially determined duration and the moment. More specifically, subjects construct the experience of time in terms of past, present and future, landmarks within a sequence which is permanently actualized. This "presentification" process constitutes both the experience and the way of experiencing time through a single movement that-as every social practice, sensation and narration of the world-is permeated by the class logic. In the case of the people pushed away to urban borders in contexts of socio-spatial segregation, this experience of time becomes an analytical key to inquire into the configuration of their sensibilities, and more specifically, of their modes of being, feeling and possessing.

To live in the periphery of the city is to be confined (both socially and corporeally) to a space of expulsion characterized by the denial of multiple rights—social, political, economical, cultural—and the lack of basic goods and services. These populations are actually inscribed in the rhythms determined by the World of No (no jobs, no health, no housing and so on), and this absence is one of the (few) certainties given to them by the city (in capital letters) from which they are permanently expelled. As a result, the subaltern classes develop an ability to "wait" for minimum standards of life as their mode of sociability within the city fragment they inhabit. This sociability lies at a very distant point from the experience of instantaneous, unlimited, fluid and aseptic access to the city comforts triggered by the new technologies. Moreover, "waiting” as an ability contrasts with the acceleration of social times boosted by the ever-faster circulation of goods and consumerism.

The following sections reflect on these topics considering a selection of scenes identified in Argentina that refer to the unequal conditions of access to basic goods and services. Two are the main assumptions underlying the analysis proposed in this article. On the one hand, it is suggested that "waiting” permeates bodies performing sensations of tiredness and helplessness that reproduce the limits and contents of a social time regulated by a logic described as "things will always be like this" ("siempre será asî"). On the other hand, the experiences of the city are understood as the result of class inter-play within fragmented urban settings. In other words, the way in which city dwellers sense and live the city is structured through a constant interaction between distances and proximities, both corporeal and social, that allows or closes certain paths.

Drawing on these assumptions, the analytical interests presented here are developed as follows. The first section presents a theoretical overview on the structuration of sensibilities and social times, particularly through the logic of absence. The second section reviews some indicators concerning access to key goods and services in Argentine cities. Lastly, the third section outlines some thoughts on social time, sensibilities and the "logic of waiting” as a mechanism of social bearability in contexts of socio-spatial segregation.

\section{Between Kronos and Kairos: Times and Social Sensibilities}

Reflections on time (its existence and nature) have captured the attention of human thought from immemorial 
times. There are perspectives that underline the duration, repetition and succession; distinctions between objective and subjective time; debates among those who consider time as reality (unstoppable, irreversible) or else as the relationship between subjects, between things and between subjects-things. These are some of the orientations that have structured classic philosophical, physical, theological, mathematical, psychological and sociological arguments on the matter. Considering time as existing independently (externally) from things and flowing in a uniform manner (Newton), as a manifestation of "Geist" (Hegel), as a form of an a priori intuition (Kant), as duration (Bergson) or as a relative dimension (Einstein), are just brief examples of the diverse conceptions of time along history. Although this article is not aimed at giving an account of the existing theoretical approaches to time, it should be pointed out that this topic permeates-more o less explicitly - the development of social sciences and the works of renowned theorists, such as Durkheim (1982), Mauss (1979), Halbwachs (1968), Merton \& Sorokin (1992), Elias (1989, 1993), Gurvitch (1964) and Merleau-Ponty (1984), among others.

As an analytical category, social time can be defined as the network of durations, rhythms, successions and irruptions that configure and qualify the sensitive and inter-subjective relationship of individuals with themselves, with worldly objects and with the others. The time dimension is intertwined with practices, bodies, narratives, memories and oblivions, while delineating them. Under the suit of an apparent totality, all times (economic time, cultural time, political time, class time, corporeal time, vital time) constitute diverse expressions of that dimension, which also embraces their interplays and inter-genesis.

Being one of the organizers of experience, social time becomes an expressive metaphor of the socio-vital sequence that pervades interactions, operating as one of the (perceptible, measurable) axes that structure the classifications and perceptions of the world that individual subjects elaborate through the triad before/now/after. The lived present is constituted, precisely, by their presentification. From this point of view, the past-present-future articulations that qualify the individual and collective biographies are not a simple line of succession "just laying out there" used to organize social phenomena, but a Möbius Band in which memories, expectations, practices, sensations and conflicts combine, tighten up, approach to and distance from each other. And it is in the context of these torsions of temporality where the corporeal and sensitive dimension becomes crucial.

In ancient Greek culture, Kronos is the word for sequential, unavoidable time. It represents the eternal rise and perish. In brief, it stands for duration (the time occurred between life and death). On the contrary, Kairos, symbolizes the right, critical or appropriate time. It breaks the continuity of the kronological sequence marked by the clock, opening the possibility of transformation. It is an instant that opens gaps, a space of time "unique and single that is not present, but always yet to come and always gone. It overflies us” (Nuñez, 2007: 5) ${ }^{1}$. It may be said, from a sociological perspective, that the conceptions of time condensed in Kronos and Kairos allow interpreting it simultaneously as the irreversible and the openness, as order and change, both in terms of mutually conditioned social and vital time. In fact, the ideas developed by Norbert Elias (1993) in his analysis of the ever-growing interdependence that conforms contemporary societies go in this direction, specially his reflections on "self-constraint" and its links to the configuration of the rhythmic dimension of social practices and sensibilities in the context of class societies:

The restraints on emotions and the regulation of impulses imposed by life within such a complex network are as strong as self-control and as constant as coercion. One of the clearest expressions of this correspondence between stronger and milder pressure by the interdependency network, on the one hand, and the individual psychic situation, on the other hand, is what we call "rhythm" of our time (...) the rhythm is the manifestation of a group of interdependent actions, of the longitude and density of the chains in which individual actions are materialized as parts of a whole, and of the force of competitive and exclusion fights that make the interdependency network move (...) the function performed in the meeting point of multiple acts along the chain requires a precise division of vital time. This division of vital time creates the habit of subordinating momentary necessities to a larger interdependence capable of excluding all behavioral oscillations and submitting them to a permanent auto-coercion (Elias, 1993: 463).

In this way, the internalized rhythm is one of the expressions of the social interdependence in which every subject is contained and framed. However, the referred temporary chain is neither individually nor collectively experienced as an imposed limitation from the outside, but as modes of being that are desired and expected in certain social contexts. This mechanism has such structuring strength in contemporary societies that being able

\footnotetext{
${ }^{1}$ The direct quotations in this article have been translated into English by the authors.
} 
to comply with and accommodate to social times constitutes one of the key elements defining "skillful" subjects within the social network. No matter how dynamic and open those social times may be, they are still reproduced in daily interactions, which guarantees their permanence and repetition. Thus, social times set up sensibilities (modes of being/doing/feeling) through incorporated (self) coercions in particular socio-historical settings.

As defined, the notion of social time enables us to enquire into social change and social reproduction processes, which we propose to think vis-a-vis the class logic conditioning the constitution of feelings, wishes and demands. Following Elias again:

(...) the "trend" inherent to the movement of civilization is everywhere the same. It always seeks a more or less automatic self-control and the subordination of short-term impulses to a long-term horizon in order to strengthen a more complex and solid "super ego" agency. The manner in which the subordination of momentary emotions to more distant goals spreads is always and everywhere more or less the same: small leading groups accept it first, and then it extends to broader and broader strata of society (Elias, 1993: 464).

As it will be shown for the Argentine case, this "subordination" of impulses and affections to the hope that "better times are yet to come" in the future is a result of the incorporation of "waiting" as a logic aimed at naturalizing the procrastination of today's wishes and necessities (Scribano, 2010). Therefore, what appears to be a mere problem of distribution of basic goods and services (such as drinking water and sanitation facilities, transport, jobs, housing, health care, and so on), turns to be an ideological mechanism that allows domination to shape class sensibilities either as hope, tiredness, helplessness or resignation. In other words, to live within the boundaries of the World of No implies learning to wait and developing patience as abilities that make possible tolerating the sum of absences from yesterday and today.

The social time (hours, days, years) experienced by these subaltern classes is constantly permeated by the certainty that reality "has always been like this", which expresses itself in the form of suffering and self-accountability. The norm is to hold on, thus making the act of "waiting" a habit, the act of persevering a daily practice, and uncertainty an "adequate" (politically correct) way of feeling. Furthermore, subaltern time is occasionally lived as "dead (coagulated) time” or it may be even incorporated as physical/biological death risk, manifestations of the "experience of lacking" unveiling the extent to which it is made flesh. To sum up, these are the (physical and symbolic) expressions of social time in populations expelled from the city comforts and frequently turned into targets of welfare policies that displace the conflicts and inequalities causing their implementation.

The above illustrates the particular constitution of the time-space dimension that nurtures, consolidates and (re)produces life experiences in the peripheries of contemporary capitalist cities. Indeed, the (historic, permanent and systematic) lack of basic urban goods and services is embodied and felt. This iteration constitutes the continent of denials in which thousands of people are thrown away and recognize themselves. Inaction and deprivation as the memory and narrative of the world are the main results of the processes described.

The internalized rhythm shaping the social relates to performative repetitions. In the case of subaltern populations, these repetitions follow the logic of displacement, i.e. leaving aside the domination substrate to which subaltern practices, demands and sensibilities owe their genesis and development (Butler, 2001; Cervio, 2010). Performatively, the pain produced by the "World of No" generates new senses and feelings through repeated displacements which transform suffering into guilt, compassion or disaffection (Scribano, 2007). As a result of these processes, helplessness, anger, tiredness and/or resignation are born as feelings that connect the lack of (basic goods and services) to the experience of the segregationist city. Nevertheless, this interpretation is by no means tied to the coagulation of action. It also points out the potential of absence and denial for the emergence of "waiting" practices that are intrinsically different from those related to pacification, making possible the manifestation of Kairos (the "the right time"). This is what could "finally" retract time from the emptiness imposed by the policies of emotions and bodies ${ }^{2}$ that make domination possible.

\section{Some Urban Scenes in Contemporany Argentina}

In the previous section, the configuration of social time has been assessed, particularly with reference to urban subaltern populations. In brief, we suggested that the "subaltern time" ("waiting" as a practice and ideological

\footnotetext{
${ }^{2}$ According to Scribano (2009: 146), "body policies" are "the strategies accepted by a society to manage the individuals' social availability. They are linked to and strengthened by emotional politics aimed at regulating the construction of social sensibilities, both being a fundamental part of power structuration mechanisms".
} 
mechanism) is produced by the incorporation (embodiment) of self-coercions in order to tolerate the sum of past/present/future absences that constitute the substrate of domination. Moreover and following Elias, we pointed out that "waiting" is made flesh as a class-specific rhythm, i.e. its configuration is conditioned by and reproduces the relational class structure. Thus, the particular spatial disposition of objects and subjects expressing a class order overlaps the social and vital time valid in a certain social network, while determining it (and vice versa).

For this reason, space emerges as an unavoidable dimension for the interpretation of social time in terms of duration and instant (Kronos and Kairos). In fact, Durkheim and Merleau-Ponty, among other classic referents, have shown to what extent time is not comprehensible independently of the spatial dimension. They are co-constituted as both properties of the social and relations among things, and as such they are instituted as the inscription surface or cronotopical coordinates of every human action. In this sense, social time and space jointly considered become resource, scene and horizon of individual and collective practices, experiences, memories and narrations of the world, because "the succession of times is also a succession of spaces that we travel across and travel across us, leaving in us the traces we leave in them” (De Sousa Santos, 1991: 116).

Following this argument, it should be noted that geographers, sociologists and anthropologists consider class conditions when discussing the structuration of space in general, and of urban spaces in particular. From a Marxist perspective, the French sociologist Henri Lefebvre $(1972,1978)$ pointed out that socially constructed spaces shape thoughts and actions. Likewise, authors such as Edward Soja reflect on this tension through the idea of "perceived, felt and lived space" and suggest that the functioning of the capitalist system may be viewed as a space-class homology manifested in the "regionalized division between dominant centers and subordinated peripheries, in the production relations socially produced and polarized, understandable in a more accurate manner through the concept of geographically unequal development” (Soja, 1993: 99). Last but not least, Yi-Fu Tuan refers to the importance of the "residential factor" in the construction of corporeality and sensibility ${ }^{3}$ (Lindón Villorio, 2009), and David Harvey (2004) proposes a "radical geography” that results from the tension between the individual and the social body, and where the body is the means and inscription surface of capitalist social relationships (D’hers, 2011).

Having said that, if we accept that the urban space is simultaneously product and production of asymmetrical social relations, and that the urban structure finds its foundations in domination relations specific to a certain time-space configuration (Lefebvre, 1972; Scribano \& Cervio, 2010), then it is evident that the spatial distribution of bodies, goods and services in twenty-first century cities is marked by an (ever-growing) extensive and intensive socio-spatial segregation connected to the accumulation pattern in the current capitalist phase.

Beyond the theoretical considerations that this statement might bring up, the spatial distribution of inequalities that delineates the landscape of actual cities can be observed in the light of empirical data related to the living conditions in their peripheries. In this context and taking into account the behavior of some indicators measured by the Argentine Social Debt Observatory, the following facts are observed for the year 2010 in Argentina: ${ }^{4}$

- $12.2 \%$ of the urban households (which represent $14.7 \%$ of the urban population) live in "inappropriate" dwellings ${ }^{5}$. Considering only shantytowns and slums, the percentage of people living in those conditions increases to $59.2 \%$.

- $12.4 \%$ of the urban households do not have access to safe drinking water, $26.8 \%$ lack natural gas connections, $34.6 \%$ are not serviced by public sewers, $32.3 \%$ do not have drainage facilities and $19.2 \%$ are located in areas without street paving.

- One out of four urban households connected to the public water supply network receives a deficient service.

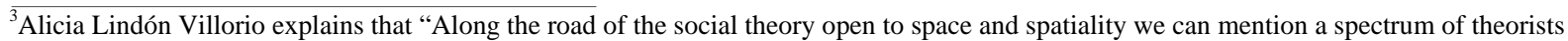
that have included space in their schemes to understand the world, such as Michel Maffesoli (1979), Michel de Certeau (1996), Erving Goffman (1970; 1981) and Isaac Joseph (1988), to name a few" (2009: 8). In addition to the authors mentioned here, Milton Santos (1990) has prominently assessed the dialectic relation between society and territory from a Latin American perspective, conceptualizing the latter as "used and appropriated space."

${ }^{4}$ The 2010 survey was carried on during the fourth trimester to a representative sample (probabilistically speaking) of urban households from different Argentine regions. Consequently, data may be generalized to all households in cities over 60 thousand inhabitants. The results of this survey are part of a broader study over the period 2010-2016 comprising yearly analyses and reports. This is one of the few up-to-date sources of data related to urban clusters given the political intervention affecting the national statistics organism (INDEC) since the beginning of 2007. Therefore, the reports it elaborates and publishes periodically lack reliability. That is the reason why we use an alternative source of data (Social Debt Observatory) in this article.

${ }^{5}$ The study considers "inappropriate dwellings" those abiding to at least one of the following conditions: a) are slums, ranches or alike; or b) are houses or apartments with solid structures and walls made of materials other than bricks and plaster (Social Debt Observatory, 2010: 54).
} 
- $15 \%$ of the urban households (which correspond to $18.2 \%$ of the urban population) do not have a mechanical flush toilette inside the housing unit. Considering shantytowns and slums independently, the percentage of houses without this sanitary technology goes up to $43.2 \%$.

- The mean overcrowding rate reaches $8.1 \%$ of Argentine urban households and $12.8 \%$ of the national population. The mentioned rate is almost tripled (22.8\%) when taking into account only housing units in shantytowns and slums.

Concerning the access to health services, data provided by the aforementioned study allow us to evaluate the proportion of houses served by public health care facilities (hospitals and primary health centers) located less than ten blocks from the dwelling, which is considered a "reasonable" walking distance (without transportation expenses) for anyone requiring medical attention. According to the 2010 measurements, 38.6\% of the urban households (37.8\% of the population) are farther than the specified distance from the nearest health care unit, a situation revealing a double distance (both spatial and economical) embodied in the subaltern classes. The referred report states that:

Over a third of the two lower [socio-economical] strata, which include the population who mainly depend on the public [health care] subsystem, do not count with a health facility near their residence, without being statistically significant the differences between those strata (Social Debt Observatory, 2010: 76).

Finally and after presenting all the measured indicators, the 2010 Social Debt Barometer Report concludes the following:

This study describes the persistence of an evident structural duality in an economy characterized by extraordinary levels of growth regarding both private employment/consumption and public expenditure. Nevertheless, these factors do not explain why the structural conditions of marginality have hardly changed (Social Debt Observatory, 2010: 34).

\section{Social Time and the Logic of Waiting as a Mechanism of Social Bearability}

The data showed in the previous section indicate that health and housing conditions are determined by accessibility, which in turn is tied up to a situation of spatial seclusion in big and medium cities. Seclusion remains a structuring feature of the life conditions and thus, of the inhabiting experiences of the populations expelled from the city comforts.

In this context, yesterday and today's lack of access connects to the "waiting” logic as a mechanism of social bearability that blurs conflict in the name of a supposedly better future narrated from the emotional and corporeal conditions embedded in marginal life. "Better times will eventually come", is often heard, and waiting is needed to keep going in the meanwhile.

Following Scribano (2007), the mechanisms of social bearability refer to a set of embodied practices operating almost without being noticed in the networks of common sense and in the construction of feelings usually appearing as an "intimate" and "unique" trait of individuals. They are oriented towards systematically avoiding the social conflict entailed by the vital energy expropriations, appropriations and depredations on which capitalism relies. More specifically, these mechanisms pose social life as a perpetual always like this and connect helplessness with a naturalization of structural lacks, reducing the painful (and conflictive) character of a neverending harsh life (Kronos).

Distance objectified in the physical remoteness from health care facilities, along with the lack of access to minimum housing standards, impede the full physical, emotional and cognitive development of subjects and emerge as central features of domination expressed within the (subaltern) experience of the city. In other words, this experience structured by multiple lacks is, in the last instance, the result of class inter-play of both social and bodily distance and proximity, which allow and limit certain paths (but not others). The ability to "wait" emerges then as the expression of both precarious living conditions and class position. In Daniel Bensaid words,

Today the privatization of the world goes far beyond the private appropriation of the production means. It reaches services, health care systems, education, housing, transport, communication; privatization of currency (...); privatization of law (preeminence of private contracts over statute law); privatization of life and organs (Bensaid, 2004: 213).

Then, the situation of dearth forces subjects to assume a "waiting" attitude, deferring joy in time in a way that 
does not necessarily correspond neither with the dominant social time, nor with vital rhythms. Every achievement is both preceded and followed by a period of "waiting": a time of expectancy that throws current necessities (and tensions) ahead, and a new expecting moment after every little step forward delimited by the conviction that it is "adequate and enough for me". In any case, the place occupied in the map of social classes causes the "waiting" logic to emerge, while setting its limits.

As a closing remark, it can be said that the logic of material and symbolic deprivation configures and is configured by the experience of being segregated and the feelings arising from inhabiting marginal fragments of the city. This logic performs the narration of a social world limited to a "sufficiency" regime which guarantees the "minimum" necessary for day-to-day reproduction. The corporeal and social limit forced by the explicit denial of certain urban goods and services is embodied as threshold of "sufficiency". Then, it configures feelings/modes of being (related to needing and waiting) deemed "adequate" and "natural" to the class substratum that features and reproduces hardship (Cervio \& D'hers, 2012). The iteration of “waiting” events linked to an accumulation of structural lacks made flesh in contexts of socio-spatial segregation transforms passivity into a prized ability to live within the social times imposed by the World of No.

This scene defined by the coagulation of action sets a theoretical and fundamentally political question: Is it possible the emergence of an agency capable of breaking the sequence of death and emptiness entailed by the siege of Kronos? Independently of the processes involved in this challenge, it is clear that they open the way for the advent of a Kairos and make a valuable contribution to social emancipation.

\section{References}

Bensaid, D. (2004). Cambiar el mundo. España: Diario Público.

Butler, J. (2001[1990]). El género en disputa. El feminismo y la subversión de la identidad. México: Paidós.

Cervio, A. L. (2010). Performatividad, fantasmas y fantasías sociales. El “encantamiento” de la (re)nominación en la gestión del hábitat social en la ciudad de Córdoba. Actuel Marx/Intervenciones, 9, 261-283.

Cervio, A. L., \& D’hers, V. (2012). Cuerpos y sensibilidades en falta. Una aproximación a la noción de necesidad en contextos de segregación socio-espacial. In A. L. Cervio (Comp.), Las tramas del sentir. Ensayos desde una sociología de los cuerpos y las emociones (pp. 115-150). Córdoba: Estudios Sociológicos Editora.

De Souza Santos, B. (1991). Una cartografía simbólica de las representaciones sociales. Nueva Sociedad, 116, 18-29.

D’hers, V. (2011). Configuraciones de la sensibilidad y Soportabilidad social en hábitats precarios. Lomas de Zamora, provincia de Buenos Aires, Argentina (2007-2011). PhD Thesis, Argentina: Universidad de Buenos Aires.

Durkheim, É. (1982). Las formas elementales de la vida religiosa. Madrid: Akal.

Elias, N. (1989). Sobre el tiempo. México: Fondo de Cultura Económica.

Elias, N. (1993). El proceso de civilización. Investigaciones sociogenéticas y psicogenéticas. Buenos Aires: Fondo de Cultura Económica.

Gurvitch, G. (1964). The spectrum of social time. Dordrecht (Holanda): Reidel.

Halbwachs, M. (1968). La mémoire collective. París: P.U.F.

Harvey, D. (2004). La condición de la posmodernidad. Buenos Aires: Amorrortu.

Lefebvre, H. (1972). La revolución urbana. Madrid: Alianza.

Lefebvre, H. (1978). El derecho a la ciudad. Barcelona: Península.

Lindon Villorio, A. (2009). La construcción socioespacial de la ciudad: El sujeto cuerpo y el sujeto sentimiento. Revista Latinoamericana de Estudios Sobre Cuerpos, Emociones y Sociedad, 1, 6-20.

Mauss, M. (1979). Sociología y antropología. Madrid: Tecnos.

Merleau-Ponty, M. (1985). Fenomenología de la percepción. Barcelona: Planeta Agostini.

Nuñez, A. (2007). Los pliegues del tiempo: Kronos, Aión y Kairós. Paperback, 4.

Social Debt Observatory (2010). Estado de situación del desarrollo humano y social. Barreras estructurales y dualidades de la sociedad argentina en el primer año del Bicentenario.

http://www.uca.edu.ar/uca/common/grupo68/files/2011-08-01-informe-barometro-deuda-social-argentina.pdf

Santos, M. (1990). Por una geografía nueva. Madrid: Espasa-Calpe.

Scribano, A. (2007). La sociedad hecha callo: Conflictividad, dolor social y regulación de las sensaciones. In A. Scribano (Comp.), Mapeando interiores. Cuerpo, conflicto y sensaciones (pp. 119-143). Córdoba: Jorge Sarmiento Editor.

Scribano, A. (2009). A modo de epÍlogo. ¿Por qué una mirada sociológica de los cuerpos y las emociones? In C. Figari, \& A. 
Scribano (Comp.), Cuerpo(s), Subjetividad(es) y Conflicto(s). Hacia una sociología de los cuerpos y las emociones desde Latinoamérica (pp. 141-151). Buenos Aires: CICCUS-CLACSO.

Scribano, A. (2010). Primero hay que saber sufrir!!! hacia una sociología de la "espera” como mecanismo de soportabilidad social. In A. Scribano, \& P. Lisdero (Comp.), Sensibilidades en juego: miradas múltiples desde los estudios sociales de los cuerpos y las emociones (pp. 169-192). Córdoba: Estudios Sociológicos Editora.

Scribano, A., \& Cervio, A.L. (2010). La ciudad neo-colonial: Ausencias, Síntomas y Mensajes del poder en la Argentina del siglo XXI. Revista Sociológica, 2, 95-116.

Soja, E. (1993). Geografías Pós-Modernas. A reafirmação do espaço na teoria social crítica. Río de Janeiro: Jorge Zahar Editor.

Sorokin, P., \& Merton, R. (1992). El tiempo social: Un análisis metodológico y funcional. In R. Ramos Torres (Comp.), Tiempo y Sociedad. Madrid: Siglo XXI. 